\title{
Asaia spp., acetic acid bacteria causing the spoilage of non-alcoholic beverages
}

\author{
Iveta Šístková*, Iveta Horsáková, Mariana Hanková, Helena Čížková \\ Department of Food Preservation, University of Chemistry and Technology Prague, Technická 5, 166 28, Prague 6, Czech \\ Republic
}

${ }^{*}$ Corresponding author iveta.sistkova@seznam.cz

\begin{abstract}
After a general introduction and introduction to acetic acid bacteria, this work focuses on the genus Asaia, which causes sensory defects in non-alcoholic beverages. Asaia representatives have strong adhesive properties for materials used in the food industry, where they subsequently form biofilms and are highly resistant to chemical preservatives. After the basic characteristics of the genus Asaia and its influence on humans, the main part of the paper deals with microbial contamination of beverages by these bacteria. The paper summarizes the knowledge of the influence of packaging materials on the development of defects in beverages and the use of natural bioactive substances and plant extracts as an alternative to maintaining the microbiological stability of beverages.
\end{abstract}

Key words: Asaia spp., soft drinks, sensory defect

\section{Introduction}

Acetic acid bacteria ( $A A B$ ) get their name because of their ability to oxidize ethanol to acetic acid (except the Asaia genus), which is used in the industry for the production of vinegar and other compounds such as L-ascorbic acid, dihydroxyacetone, gluconic acid, sorbose, and cellulose (Mamlouk and Gullo, 2013). Research on AAB focuses mainly on vinegar, wine, cocoa and coffee, which are raw materials of major importance in the food industry. On the one hand, the use of $A A B$ as starter cultures in vinegar production can lead to an improvement in the fermentation process and an increase in the quality of the final product, whereas on the other hand their occurrence in wine is undesirable because it increases the content of volatile acids (Sengun and Karabiyikli, 2011). Many AAB tolerate preservatives commonly used in the beverage industry (benzoates, sorbates, dimethyl dicarbonate) (Juvonen et al., 2011) and therefore cause microbial spoilage of beverages (Kregiel et al., 2012; Horsáková et al., 2009; Moore et al., 2002; Kregiel and Antolak, 2016).

\section{Acetic acid bacteria}

The group AAB (Acetobacteraceae) includes gramnegative, aerobic, non-sporeforming bacteria, ellipsoid to rod-shaped (Fig. 1). Their size ranges from 0.4 to $1 \mu \mathrm{m}$ in width and from 0.8 to $4.5 \mu \mathrm{m}$ in length (Sengun and Karabiyikli, 2011). They can occur individually, in pairs or in chains. The optimal growth conditions are: $\mathrm{t}=25-30$ ${ }^{\circ} \mathrm{C}$ and $\mathrm{pH} 5-6.5$, and they are able to grow even at $\mathrm{pH}$ $<3$ (Juvonen et al., 2011). AAB obtain energy from, for example, the oxidation of sugars, organic acids, sugar alcohols, and alcohols, while producing acetic, gluconic, lactic and succinic acids, acetaldehyde and ketone compounds. Final products depend on the type of bacteria and the growth conditions (Juvonen et al., 2011). No glycolysis is performed due to the lack of phosphofructokinase enzyme. $A A B$ were isolated from plants, fruits, fermented foods and beverages, or insects (Crotti et al., 2010). The AAB taxonomy is still evolving due to the limited knowledge of their phylogenesis and the difficult isolation and problematic conservation of these strains (De Vero and Giudici, 2008). AAB had previously been divided into two genera: Acetobacter (first described in the literature in 1898) and Gluconobacter (1935) (Yamada et al, 2008). Acetobacter bacteria were isolated from vinegar, alcoholic beverages (beer, sake, wine, cider, tequila), pickled cucumbers, fruit (grapes, mango, bananas, papaya, etc.), flowers and other materials.

Acetobacter's alcohol dehydrogenase activity is more stable in an acidic environment than that of the Gluconobacter genus; therefore it generates greater amounts of acetic acid (Sengun et al, 2011). Based on 16S rRNA sequencing, it was found that some of the Acetobacter bacteria contain Q-10 as the main ubiquinone, whereas other bacteria of the genus contain ubiquinone Q-9 as the main one. Bacteria with ubiquinone Q-10 were then placed in a new genus Gluconacetobacter. Bacteria of the genus Gluconobacter are often found in fruit products, they thrive in a sweet environment such as fruits, cider, beer, and non-alcoholic beverages (Gammon et al., 2007). They are considered to be the most common contaminants of low $\mathrm{pH}$ soft drinks, as they are resistant to preservatives such as sorbic acid, benzoic acid and dimethyl dicarbonate (Sengun and Karabiyikli, 2011). Nowadays, thanks to the $16 \mathrm{~S}$ rDNA sequencing, taxonomy is being refined and it divides the $A A B$ into more than twenty genera: Acetobacter, Gluconobacter, Acidomonas, Gluconacetobacter, Asaia, Kozakia, Swaminathania, 

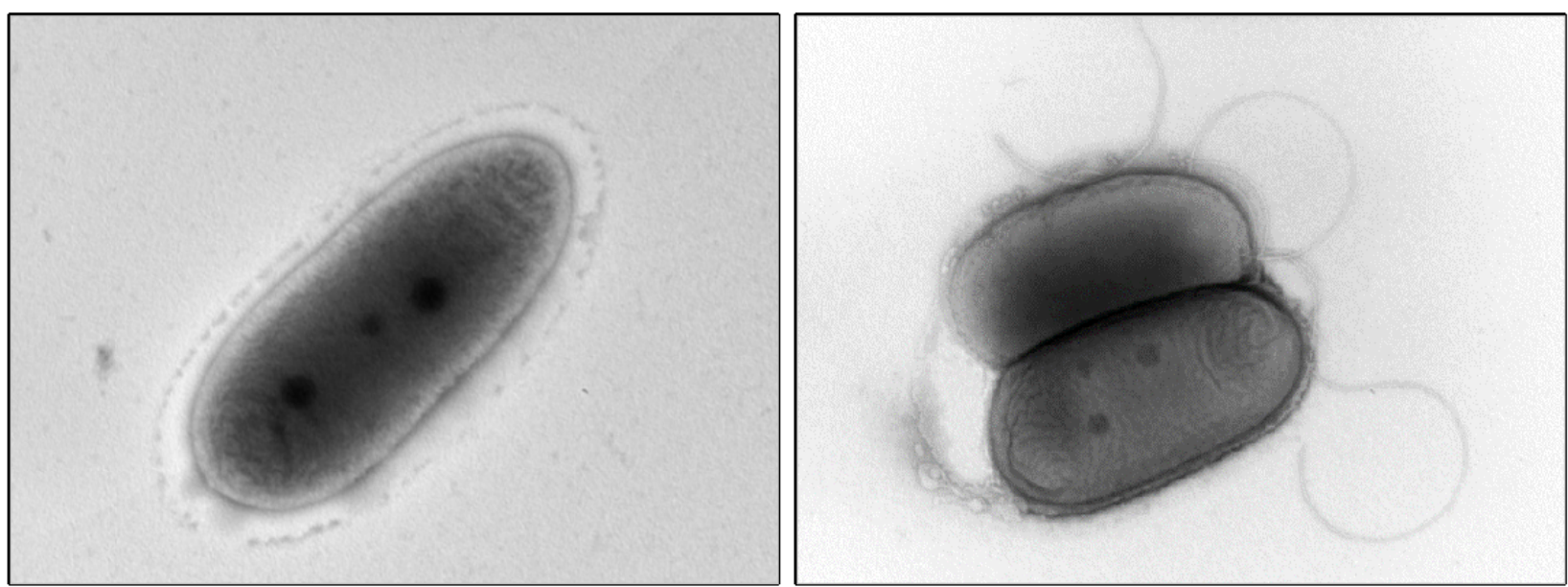

Figure 1: Bacteria of the genus Asaia (left, magnification 30000x) and Gluconacetobacter liquefaciens (right, magnification 25000x) (the picture was taken at the Department of Biochemistry and Microbiology with an electron microscope, author doc. Ing. Pavel Ulbrich, Ph.D.)

Saccharibacter, Neoasaia, Granulibacter, Tanticharoenia, Acidiphilium, Acidisphaera, Acidocella, Craurococcus, Paracreurococcus, Rhodopila, Roseococcus, Roseomonas, Stella, Zavarzin and Ameyamaea (Sengun et al, 2011; Sievers et al, 2006). The genera Acetobacter, Gluconacetobacter, Gluconobacter, Asaia, and Saccharibacter live in symbiosis with Drosophila melanogaster and Bactrocera oleae, mosquitoes of the genera Anopheles and Aedes, honey bee Apis mellifera, Scaphoideus titanus, and Saccharicoccus sacchari, in which they colonize their digestive tract (availability of nutrients), but may also occur in other parts of the body or on its surface (Crotti et al., 2010). Bacteria of the genus Asaia, unlike other acetic acid bacteria, are unable to (or can only slightly) oxidize ethanol to acetic acid (Crotti et al., 2010). Further differences are shown in Table 1.

Table 1: Different properties of the genus Asaia and the selected genera of acetic acid bacteria (taken from Yamada et al., 2000); $w=$ weak; $+=$ positive, $-=$ negative

\begin{tabular}{|c|c|c|c|c|c|}
\hline Characteristic & Asaia & Acetobacter & Gluconobacter & Acidomonas & Gluconoacetobacter \\
\hline Flagellation & $\begin{array}{c}\text { peritrichous } \\
\text { / none }\end{array}$ & $\begin{array}{l}\text { peritrichous } \\
\text { / none }\end{array}$ & polar / none & none & peritrichous / none \\
\hline $\begin{array}{l}\text { Oxidation of: } \\
\text { - } \text { Acetate } \\
\text { - } \quad \text { Lactate }\end{array}$ & $\begin{array}{l}+ \\
+\end{array}$ & $\begin{array}{l}+ \\
+\end{array}$ & $\begin{array}{l}- \\
-\end{array}$ & $\begin{array}{l}+ \\
-\end{array}$ & $\begin{array}{l}+/- \\
+/-\end{array}$ \\
\hline Growth on methanol & - & - & - & + & - \\
\hline $\begin{array}{l}\text { Assimilation of ammonium sulfate } \\
\text { on glucose medium }\end{array}$ & + & $w^{+}$ & - & - & $w^{+}$ \\
\hline $\begin{array}{l}\text { Growth on: } \\
\text { - } \quad \text { Glutamate agar } \\
\text { - } \quad \text { Mannitol agar }\end{array}$ & $\begin{array}{l}+ \\
+ \\
\end{array}$ & $\begin{array}{l}+/- \\
-/+\end{array}$ & $\begin{array}{l}- \\
+ \\
\end{array}$ & $\begin{array}{l}- \\
- \\
\end{array}$ & $\begin{array}{l}+/- \\
+/-\end{array}$ \\
\hline Dihydroxyacetone from glycerol & $-/ w^{+}$ & $-/ w^{+}$ & + & - & $+/-$ \\
\hline $\begin{array}{l}\text { Acetic acid production } \\
\text { on ethanol- } \mathrm{CaCO}_{3} \text { agar }\end{array}$ & $-/ w+$ & + & + & + & + \\
\hline $\begin{array}{l}\text { Growth on acetic acid-containing } \\
\text { medium }(0,35 \%)\end{array}$ & - & + & + & + & + \\
\hline 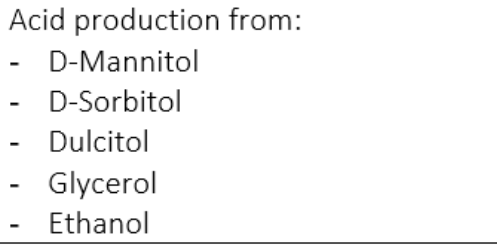 & $\begin{array}{c}+/- \\
+/- \\
+ \\
+ \\
-/ w+\end{array}$ & $\begin{array}{c}-/+ \\
- \\
- \\
- \\
+ \\
\end{array}$ & $\begin{array}{l}+ \\
+ \\
- \\
+ \\
+\end{array}$ & $\begin{array}{l}- \\
- \\
- \\
- \\
+\end{array}$ & $\begin{array}{c}+/- \\
- \\
- \\
+ \\
+ \\
\end{array}$ \\
\hline DNA base composition ( $\mathrm{mol} \% \mathrm{G}+\mathrm{C}$ ) & $59-61$ & $53-63$ & $54-63$ & $3-66$ & $55-66$ \\
\hline Major ubiquinone & $Q-10$ & Q-9 & Q-10 & Q-10 & Q-10 \\
\hline
\end{tabular}



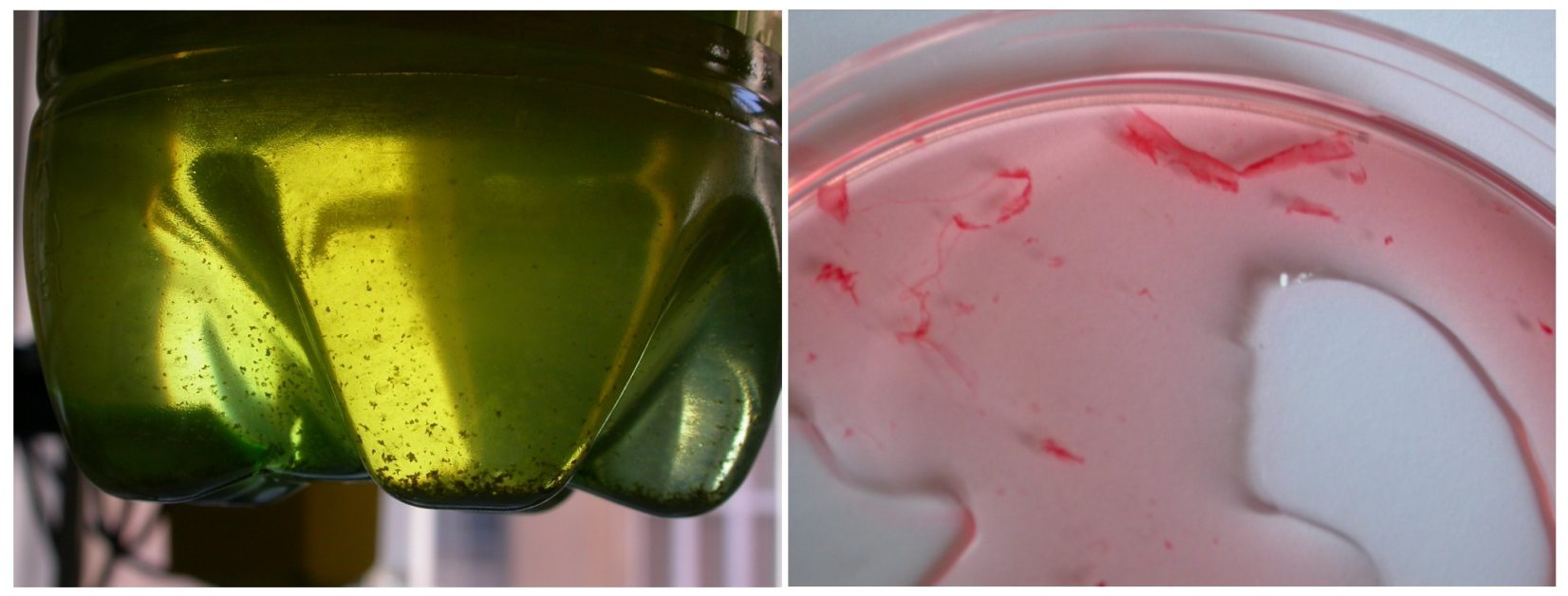

Figure 2: Shown on the left: sediment in a bottle of green tea formed by AAB; shown on the right: Asaia cell coagulation in a fruit drink (the pictures were taken at the Department of Food Preservation with Nikon Coolpix 4500, author Iveta Horsáková, Ph.D.)

This group of bacteria was classified based on the similarity of $16 \mathrm{~S}$ rRNA sequencing. To date, 8 species have been identified in the genus Asaia: $A$. astilbis, $A$. bogorensis, A. krungthepensis, A. lannensis, A. platycodi, A. prunellae, $A$. siamensis and $A$. spathodeae (LPSN, 2018). Asaia is a gram-negative fermenting bacterium forming a sharply defined pale pink colonies on Sabouraud agar. Asaia is catalase positive, oxidase negative with optimal growth at temperatures of 22 to $30{ }^{\circ} \mathrm{C}$. Its growth is limited at temperatures above $37{ }^{\circ} \mathrm{C}$, it does not grow in $0.35 \%$ acetic acid medium and in the presence of methanol. Resistance to several antibiotics used against gram-negative bacteria (ceftazidime, meropenem, imipenem, trimethoprim, amikacin, vancomycin, aztreonam, penicillin, and ampicillin) has been identified (Moore et al., 2002). As acetic acid bacteria, it is able to grow at low $\mathrm{pH}$ values $(\mathrm{pH}<3$ ) (Kregiel, 2013) and non-carbonated non-alcoholic beverages are therefore a suitable medium for the growth of these bacteria. In nature, Asaia occurs in the tropical flora of Bauhinia purpurea and Plumbago auriculate and as the symbiotic bacterium of Anopheles mosquitoes (Crotti et al., 2010; Yamada et al., 2000).

Although these bacteria are not pathogens, the literature describes cases of the occurrence of Asaia bacteria in humans. Asaia bogorensis is the first bacterium of $A A B$ that has been associated with human infection. It was isolated from a fluid from peritoneal dialysis in a patient with diabetes in the last stage of renal failure in 2004 (Snyder et al., 2004). In the following year, Asaia was isolated from the blood of a drug-dependent patient with an operative knee arthritis (Tuuminen et al., 2006). The occurrence of Asaia bogorensis was also reported in a two-year-old child with cystic fibrosis (Alauzet et al., 2010). Asaia lannensis, which differs from most of the Asaia genus bacteria by the formation of acetic acid from ethanol, was reported in 2009 as the cause of bloodstream infection in three year old boy with bone marrow transplant (Abdel-Haq et al., 2009) and one year later in two girls with dilated cardiomyopathy (Juretschko et al., 2010). It should be mentioned that only six cases of infections caused by Asaia bacteria were reported between 2004-2012 and, in all of these cases, the infection was reported in immunosuppressed patients. No Asaia bacteria were detected in an analysis of blood from healthy donors; therefore, the bacteria of the genus Asaia can only be considered as rare opportunistic pathogens (Epis et al., 2012).

\section{Genus Asaia as a microbial contami- nant of non-alcoholic beverages}

Proliferation and surface contamination with Asaia bacteria in the beverage industry is becoming a serious problem. Even the significantly low $\mathrm{pH}$ of beverages and the presence of chemical preservatives are unable to prevent the growth of these microorganisms (Kregiel et al., 2018). The origin of Asaia as contaminating bacteria in the beverage industry is unclear. Moore et al. (2002) assume that it comes from the natural ingredients of recipes such as tea extracts. The growth of Asaia bacteria leads to turbidity and formation of floating particles in the contaminated finished product (see Fig. 2) (Kregiel et al., 2009; Horsáková et al., 2009; Moore et al., 2002).

Kregiel et al. (2018) identified cell coagulation in defective/spoiled samples of non-alcoholic beverages. These coagulations included bacteria of the genus Asaia and yeasts belonging to three distinct species, namely 
Wickerhamomyces anomalus, Dekkera bruxellensis and Rhodotorula mucilaginosa. Asaia bacteria were responsible for the formation of flakes in non-alcoholic beverages, yeast cells helped to strengthen the overall flake structure.

Bacteria of the genus Asaia have strong adhesion ability to materials used in the food industry and are thus able to produce very resistant biofilms in the production facilities (Yamada et al., 2000; Sedláčková et al., 2011; Horsáková et al., 2009). The biofilm formed on the solid surfaces of the production line may then be the source of secondary contamination of the final products. The initial key step leading to biofilm formation is the adhesion of bacteria to the surface. It is a complex process influenced by the different physical and chemical properties of microbial cells, media and abiotic surfaces (Antolak et al., 2016b). The adhesion of Asaia cells thus depends not only on the type of the medium, carbon sources and nutrients but also on the type of the surface material. It has been shown that mineral water with strawberry flavor provides more favorable conditions for the formation of Asaia genus biofilm compared to a medium containing a minimal amount of nutrients (Antolak et al., 2016a). The type of surface material, its roughness and hydrophobicity significantly affect the attachment of bacteria and growth of biofilm. Bacteria $A$. lannensis and $A$. bogorensis show a stronger adhesion to plastic (hydrophobic) than glass (hydrophilic) surfaces (Antolak et al., 2016a).

Kregiel and Antolak (2016) published a study about the effect of packaging material on the growth of Asaia bacteria in flavored mineral waters. They demonstrated that the $A$. bogoresis and $A$. lannensis strains were growing faster in PET (polyethylene terephthalate) bottles of a small volume ( 0.33 and 0.5 liters) compared to larger glass bottles. Smaller bottles provide a larger contact area for the liquid with the container surface where the bacteria can attach. Compared to traditional glass bottles, PET bottles are to a certain degree permeable to small molecules such as gases, water and other low-molecular compounds (aroma, flavor, and other additives). An increased risk of microbial growth in beverages packaged in PET is also due to an increase in oxygen content during storage. From this perspective, glass bottles of more than 0.7 liters capacity are the appropriate choice to increase the microbial stability of the final product.

Due to the resistance of Asaia bacteria to chemical preservatives, attention is now focused on the use of natural bioactive substances such as polyphenols, saponins and organic acids (Antolak et al., 2016a). A study has shown that $10 \%$ ethanol extract of peppermint (Mentha piperita L.) restricts the adhesion of bacterial cells of the genus Asaia ( $A$. lannensis and $A$. bogorensis) to polystyrene, an approved food contact material (Antolak et al., 2016a). In another study (Antolak et al., 2017), the antibacterial and anti-adhesive effects of ethanol extracts from five edible parts of plants were investigated: cinnamon bark (Cinnamomum zeylanicum), lico- rice root (Glycyrrhiza radix), nettle leaves (Urtica dioica), green tea leaves (Camellia sinensis) and elderberry flowers (Sambucus nigra). The medium containing 10\% of the elderberry flowers extract provided the least favorable environment for the growth of tested bacterial strains of the genus Asaia ( $A$. lannensis and $A$. bogorensis). Also, green tea, cinnamon, and licorice extracts have proven inhibitory effects on bacterial cell adhesion. All of the mentioned extracts contained phenolic compounds (e.g. gallic, chlorogenic, neochlorogenic, caffeic, coumaric and felucic acid) and a number of flavonoids (flavanols, flavonols, flavanones).

In addition to plant extracts, juices with a high content of polyphenolic compounds were also tested on Asaia species ( $A$. lannensis and $A$. bogorensis). The addition of blueberry juice (Vaccinium myrtillus L.) and blackcurrant juice (Ribes nigrum L.) to the growth medium significantly reduced the growth of bacteria and their adhesion to the tested PET surface (Antolak et al., 2016b). In particular, blueberry juice, characterized by a higher content of polyphenols, including proanthocyanidin type $A$, has strong antiadhesive and bacteriostatic properties. The high content of bioactive compounds with proven health-enhancing properties makes these juices a valuable addition to non-alcoholic beverages as well as an interesting alternative to chemical preservatives to maintain the microbial stability of final products.

\section{Conclusion}

From the above, it is clear that bacteria of the genus Asaia are a new player in the field of soft drink spoilage. Resistance to preservatives, adhesion and biofilm formation on packaging material or production equipment materials increase the possibility of contamination of the final product, thereby reducing the quality and microbiological safety of the beverage. An interesting way to restrict bacterial development not only of the Asaia genus is the addition of bioactive compounds, whether in the form of extracts or in natural juices with their high content. 


\section{References}

Abdel-Haq, N., Savaçsan, S., Davis, M., Asmar, B. I., Painter T., Salimnia, H., 2009: Asaia lannaensis bloodstream infection in a child with cancer and bone marrow transplantation. J. Med. Microbiol., 58, 974-976. DOI: 10.1099/jmm.0.008722-0

Alauzet, C., Tyssier, C., Jumas-Bilak, E., Gouby, A., Chiron, R., Rabaud, Ch., Counil, F., Lozniewski, A., Marchandin, H., 2010: Gluconobacter as well as Asaia species, newly emerging opportunistic human pathogens among acetic acid bacteria. J. Clin. Microbiol., 48, 3935-3942. DOI: 10.1128/JCM.00767-10

Antolak, H., Czyzowska, A., Kregiel, D., 2016a: Anti-adhesion activity of mint (Mentha piperita L.) leaves extract against beverage spoilage bacteria Asaia spp. Biotechnol. Food Sci., 80, 119-127.

Antolak, H., Czyzowska, A., Kregiel, D., 2016b: Black currant (Ribes nigrum L.) and bilberry (Vaccinium myrtillus L.) fruit juices inhibit adhesion of Asaia spp. BioMed Res. Int., 14. DOI: 10.1155/2016/3671306

Antolak, H., Czyzowska, A., Kregiel, D., 2017: Antibacterial and antiadhesive activities of extracts from edible plants against soft drink spoilage by Asaia spp. J. Food Prot., 80, 25-34. DOI: 10.4315/0362-028X.JFP-16-134

Crotti, E., Rizzi, A., Chouaia, B., Ricci, I., Favia, G., Alma, A., Sacchi, L., Bourtzis, K., Mandrioli, M., Cherif, A., Bandi, C., Daffonchio, D., 2010: Acetic acid bacteria, newly emerging symbionts of insects. Appl. Enviro. Microbiol., 76, 6963-6970. DOI: $10.1128 / A E M .01336-10$

De Vero, L., Giudici, P., 2008: Genus-specific profile of acetic acid bacteria by $16 \mathrm{~S}$ rDNA PCR-DGGE. Int. J. Food Microbiol., 125, 96-101. DOI: 10.1016/j.ijfoodmicro.2007.02.029

Epis, S., Gaibani, P., Ulissi, U., Chouaia, B., Ricci, I., Damiani, C., Sambri, V., Castelli, F., Buelli, F., Daffonchio, D., Bandi, C., Favia, G., 2012: Do mosquito-associated bacteria of genus Asaia circulate in humans? Eur. J. Clin. Microbiol. Infect. Dis., 31, 1137-1140. DOI: 10.1007/s10096-011-1419-3.

Horsáková, I., Voldřich, M., Ceřovský, M., Sedláčková, P., Šicnerová, P., Ulbrich, P., 2009: Asaia sp. as a bacterium decaying the packaged still fruit beverages. Czech J. Food Sci., 27, S366-S368. DOI: 10.17221/970-CJFS

Juretschko, S., Beavers-May, T. K., Stovall, S. H., 2010: Nosocomial infection with Asaia lannensis in two paediatric patients with idiopathic dilated cardiomyopathy. J. Med. Microbiol., 59, 848-852. DOI: 10.1099/jmm.0.019067-0

Juvonen, R., Virkajärvi, V., Priha, O., Laitila, A., 2011: Microbiological spoilage and safety risks in noon-beer beverages produced in a brewery environment. Espoo, VTT Tiedotteita - Research Notes 2599. ISBN 978-951-38-7787-3

Kregiel, D., Rygala, A., Libudzisz, Z., Walczak, P., OltuszakWalczak, E., 2012: Asaia lannensis - the spoilage acetic acid bacteria isolated from strawberry-flovored bottled water in Poland. Food Control, 26, 147-150. DOI: 10.1016/j.foodcont.2012.01.020.
Kregiel, D., 2013: Attachment of Asaia lannensis to materials commonly used in beverage industry. Food Control, 32, 537-542. DOI: 10.1016/j.foodcont.2013.01.037.

Kregiel, D., Antolak, H., 2016: Growth of Asaia spp. in flavored mineral water - evaluation of the volumetric "bottle effect". Int. J. Food Process. Technol., 3, 62-65. DOI: 10.15379/24089826.2016.03.02.05

Kregiel, D., James, S. A., Rygala, A., Berlowska, J., Antolak, H., Pawlikowska, E., 2018: Consortia formed by yests and acetic acid bacteria Asaia spp. in soft drinks. Antonie van Leewenhoek, 111, 373-383. DOI: 10.1007/s10482-017-0959-7

LPSN (online): List of prokaryotic names with standing in nomenclature - genus Asaia.

www.bacterio.net/asaia.html (cit. 2018-08-27)

Mamlouk, D., Gullo, M., 2013: Acetic acid bacteria: physiology and carbon sources oxidation. Indian J. Microbiol., 53, 377-384. DOI: $10.1007 / \mathrm{s} 12088-013-0414-z$

Moore, J. E., McCalmont, M., Xu, J., Millar, B. C., Heaney, N., 2002: Asaia sp., an unusual spoilage organism of fruit-flavoured bottled water. Appl. Environ. Microbiol., 68, 4130-4131. DOI: 10.1128/AEM.68.8.4130-4131.2002.

Sedláčková, P., Ceřovský, M., Horsáková, I., Voldřich, M., 2011: Cell surface characteristic of Asaia bogorensis - spoilage microorganism of bottled water. Czech J. Food Sci., 29, 457-461. DOI: 10.17221/96/2011-CJFS.

Sengun, I. Y., Karabiyikli, S., 2011: Importance of acetic acid bacteria in food industry. Food Control, 22, 647-656. DOI: 10.1016/j.foodcont.2010.11.008

Sievers, M., Swings, J. 2006: Family II. Acetobacteraceae. In: Brenner, D. J., Krieg, N. R., Staley, J.T.

(Eds.): Bergey's Manual of Systematic Bacteriology, 2nd edition, vol. 2, The Proteobacteria, Part C. Springer. pp. 41-95.

Snyder, R. W., Ruhe, J., Kobrin, S., Wasserstein, A., Doline, C., Nachamkin, I., Lipschutz, J. H., 2004: Asaia bogorensis peritonitis identified by $16 \mathrm{~S}$ ribosomal RNA sequence analysis in a patient receiving peritoneal dialysis. Am. J. Kidney Dis., 44, e15-e17. DOI: 10.1053/j.ajkd.2004.04.042

Tuuminen, T., Heinäsmäki, T., Kerttula, T., 2006: First report of bacteremia by Asaia bogorensis, in a patient with a history of intravenous-drug abuse. J. Clin. Microbiol., 44, 3048-3050. DOI: 10.1128/JCM.00521-06.

Yamada, Y., Katsura, K., Kawasaki, H., Widyastuti, Y., Saono, S., Seki, T., Uchimura, S., Komagata, K., 2000: Asaia bogorensis gen. nov., sp. nov., an unusual acetic acid bacterium in the $\alpha$ Proteobacteria. Int. J. Syst. Evol. Microbiol., 50, 823-829. DOI: 10.1099/00207713-50-2-823.

Yamada, Y., Yukphan, P., 2008: Genera and species in acetic acid bacteria. Int. J. Food Microbiol., 125, 15-24. DOI: 10.1016/j.ijfoodmicro.2007.11.077. 